\title{
Interaction between a variant of chromosome 9p21.3 locus and diet antioxidant capacity on metabolic syndrome in Tehrani adults
}

\author{
Atieh Mirzababaei ${ }^{1,2}$, Mehdi Mollahosseini ${ }^{1}$, Mohammad Hossein Rahimi ${ }^{1}$, Mir Saeed Yekaninejad²,
} Zhila Maghbooli ${ }^{*^{*}}$, Reza Sobhani ${ }^{1}$ and Khadijeh Mirzaei ${ }^{1^{*}}$

\begin{abstract}
Background: Genome-wide association studies have shown that risk alleles on chromosome 9p21.3 locus, are associated with increasing the risk of cardiovascular diseases (CVDs). Several epidemiological studies have found that metabolic syndrome (MetS) is associated with CVDs. Dietary antioxidants also have shown to have potential favorable effects on MetS prevention. This study examined the interactions between rs1333048 genotypes on 9p21 genetic region and Total antioxidant capacity (TAC) on odds of MetS.

Methods: 263 Tehrani adults were enrolled in this cross-sectional study. The MetS was defined according to the ATPIII. Dietary intake was assessed daily using a FFQ with 147 items. Dietary TAC was assessed according to United States Department of Agriculture database for oxygen radical absorbance capacity (ORAC). Bioelectrical impedance analysis method was used for body analysis and rs 1333048 were genotyped by restriction fragment length polymorphism method. Participants were categorized into three groups based on rs1333048 genotypes.

Results: The results demonstrate that, prevalence of $C$ allele was $52.85 \%$ and $A$ allele was $47.15 \%$. After adjustment for confunder variable, this study demonstrated an interaction between AA genotype and high Lyophilic oxygen radical absorbance capacity (L-ORAC) and high Hydrophilic oxygen radical absorbance capacity (H-ORAC) intake on low odds of MetS $(\mathrm{OR}=0.24,95 \% \mathrm{Cl}=0.06-0.94$, $\mathrm{P}$ for interaction $=0.04, \mathrm{OR}=0.26,95 \% \mathrm{Cl}=0.06-0.99$, $\mathrm{P}$ for interaction $=0.04$ ). Also, our result indicated, there was no interaction between AA genotype and high total oxygen radical absorbance capacity (T-ORAC) and total phenolic intakes on reduce odds of MetS $(\mathrm{OR}=0.07,95 \% \mathrm{Cl}=0.07-1.10$, P for interaction $=0.07, \mathrm{OR}=0.58,95 \% \mathrm{Cl}=0.16-2.07$, $\mathrm{P}$ for interaction $=0.40$ ) respectively.
\end{abstract}

Conclusion: The results of the present study indicate that high L-ORAC and high H-ORAC intake may modify the elevated odds of MetS in AA genotype of rs1333048 on the 9p21 genetic locus.

Keywords: CDKN2B, Oxygen radical absorbance capacity, Antioxidants, Metabolic syndrome, Cardio-vascular diseases, Nutrigenomics

\footnotetext{
*Correspondence: z-maghbooli@sina.tums.ac.ir; mina_mirzaei101@yahoo.com

${ }^{1}$ Department of Community Nutrition, School of Nutritional Sciences and Dietetics, Tehran University of Medical Sciences (TUMS), P.O. Box:

14155-6117, Tehran, Iran ${ }^{3}$ Endocrinology and Metabolism Clinical Sciences

Institute, Tehran University of Medical Sciences (TUMS), Tehran,

Iran

Full list of author information is available at the end of the article
} 


\section{Background}

Metabolic syndrome (MetS) is a growing public health problem worldwide, one which increases the risk of the development and progression of cardiovascular diseases (CVDs) [1]. MetS and its components, including hyperglycemia, hypertension, dyslipidemia and abdominal obesity have been indicated to be strongly associated with oxidative stress; a condition which is characterized by excessive production of reactive oxygen species (ROS) and/or lipid peroxidation, as well as diminished antioxidant protection. Previous studies have shown increased production of oxidant biomarkers and decreased levels of antioxidant defense in patients with MetS. Oxidative stress impairment or altered antioxidant status have been suggested as effective keys in the onset of certain chronic diseases such as CVDs, MetS [2]. Moreover, oxidative stress seems to be associated with the development of chronic heart diseases (CHDs) and metabolic complications among patients with MetS [3]. Increased oxidative stress underlies the pathophysiology of hypertension [4] and CVDs [5] by directly affecting vascular wall cells and decreases insulin secretion from pancreatic $\beta$ cells [6].

Reports indicate that diet antioxidants can protect against oxidative damage and related inflammatory complications [7]. Thus, a high intake of antioxidants is associated with reduced mortality [8]. Since that the concentration of single antioxidants may not reflect the total antioxidant power of food, as well as other possible interactions or synergetic effects of antioxidants, the concept of total antioxidant capacity (TAC) was introduced for investigating the beneficial effects of dietary antioxidants occurring in mixed diets as well as an approach to food characterization [9-11]. The dietary TAC describes the ability of food antioxidants to scavenge free radicals, and it is measured using the oxygen radical absorbance capacity (ORAC) assay. Recently cross-sectional studies reported that dietary TAC positively associated with plasma total antioxidant capacity $[12,13]$.

In addition to environmental factors (including lifestyle) that can increase the risk of CVDs, it can also be influenced by genetic variants and several genomic regions have been linked to risk of CVDs [14]. Genomewide association studies (GWAS) have been successful in identifying the same susceptibility locus on chromosome9p21 that associate with multifactorial diseases. Studies indicate that the 9p21 alleles contributed to CVDs risk by stimulating ectopic fat accumulation, hypertension and impaired glucose metabolism $[15,16]$. Some of these studies have investigated the possible association between single nucleotide polymorphisms (SNPs) at this locus with MetS and its components as important risk factors for CVDs as well as their interaction with environmental factors such as dietary intake [17].
Overall, diet plays an important role in the development of CHDs, several studies showed that low consumption of fruits, vegetables and fish which contains high antioxidants and protects the heart are associated with CVDs [18] and changes in diet clearly have modified CVDs risk factors [19]. Today, knowledge of how such diet related risk factors may interact with genetic susceptibility variants on CVDs risk is important for CVDs prevention.

However, based on our search no available study has evaluated the interaction between these SNPs and dietary antioxidant capacity on MetS and its components. In this study, the interactions between dietary TAC and chromosome 9 p21 polymorphism rs 1333048 on odds of MetS were investigated.

\section{Methods and materials \\ Study population}

In this cross-sectional study, 363 participants (1855 years) were enrolled. Sampling was done with advertising in the city. Individuals were included if they met following criteria: namely age 18-55, no smoking and alcohol. Participants with a history of CVDs, diabetes, cancer or stroke were excluded because of possible disease-related changes in diet and who were taking any therapeutic medications. We also excluded subjects whose reported daily energy intakes were $800 \mathrm{kcal} /$ day $(3347 \mathrm{~kJ} /$ day) or $4200 \mathrm{kcal} /$ day $(17573 \mathrm{~kJ} /$ day) [27]. These exclusions left 263 subjects (125 men and 138 women) for the current analysis. Each participant was completely informed about the study protocol and provided a written and informed consent form before taking part in the study. The study protocol has approved by the ethics committee of Endocrinology and Metabolism Research Center of Tehran University of Medical Sciences (TUMS) with the following identification: 93-04-161-27-722-1495-80.

\section{Measurement of biochemical parameters}

All blood samples were collected at 8:00 to 10:00 A.M. after having 8-12 $\mathrm{h}$ fasting state at the EMRC laboratory of Shariatei hospital of TUMS. To collect serums, Serum samples were centrifuged $10 \mathrm{~min}$ at $3000 \mathrm{rpm}$, aliquoted into $1 \mathrm{ml}$ tubes and stored at -80 until they were analyzed. Fasting plasma glucose (FPG) was measured on the day of blood collection by glucose oxidase phenol 4-aminoantipyrine peroxidase (GOD/PAP) method. Serum triglycerides (TG) concentrations were assayed with triacylglycerol kits (Pars Azmoon Inc, Tehran, Iran) by using glycerol-3-phosphate oxidase phenol 4-aminoantipyrine peroxidase (GPOPAP) method. Total cholesterol levels were measured by the Enzymatic Endpoint method and direct high- and low-density lipoprotein was measured by enzymatic clearance assay. Serum hyper sensitive 
C-reactive protein (hsCRP), as a sensitive marker of inflammation, was measured by an immunoturbidimetric assay (Randox laboratories kit, Hitachi LTD, Tokyo, Japan). Serum insulin concentrations were analyzed through enzyme-linked immunosorbent assay (ELISA) method (Human insulin ELISA kit, DRG Pharmaceuticals, $\mathrm{GmbH}$, Germany), and the minimum detectable concentration was $1.76 \mathrm{U} / \mathrm{ml}$, Intra $\mathrm{CV}$ was $2.19 \%$ and Inter CV was $4.4 \%$.

\section{Anthropometric measurements}

Weight was measured while the subjects were minimally clothed and not wearing shoes. Weight was measured to the nearest $100 \mathrm{~g}$ by using digital scales. Height was measured by using a tape measure while the subject was in a standing position and not wearing shoes, and the shoulders were relaxed. Body mass index (BMI) was also calculated using the "weight $(\mathrm{kg}) /$ height $^{2}\left(\mathrm{~m}^{2}\right)$ "equation. Blood pressure (BP) was measured using a standardized sphygmomanometer after $5 \mathrm{~min}$ of rest. Waist circumference (WC) was measured in the middle point of iliac crest and rib cage.

\section{Complete body composition analysis}

Participant's body composition was assessed through Body Composition Analyzer BC-418MA-Tanita (United Kingdom). This Bioelectrical Impedance Analyzer (BIA) is designed send out a very weak electric current to measure the impedance (electrical resistance) of the body. We followed all of the following instructions for an accurate measurement. To prevent a possible discrepancy in measured values, before assessing body composition, Participants were asked not to exercise vigorously, carry out any electric device and intake excessive fluid or food; they were performed in the morning in a fasting condition and urinate just before body composition analysis to get a more accurate result of the measurements.

\section{Dietary assessment and dietary TAC calculation}

Dietary data was collected using a validated semi-quantitative food frequency questionnaire (FFQ) with 147 food items. Trained dietitians asked participants to designate their intake frequency for each food item consumed during the past year on a daily, weekly or monthly basis. Portion sizes of consumed foods were reported in household measures, and were then converted to grams [20].

Due to the fact that the Iranian Food composition table (FCT) is incomplete, and has limited data on the nutrient content of raw foods and beverages, the US Department of Agriculture (USDA) FCT [21] was used in order to analyze foods and beverages for their energy and nutrient content. Dietary TAC describes the ability of food antioxidants to scavenge free radicals, and it is measured using ORAC assay [22]. The ORAC is one of the common methods to evaluate the antioxidant capacity [38]. The antioxidant capacity of lipophilic and hydrophilic antioxidants in the samples are evaluated using Lyophilic-oxygen radical absorbance capacity (L-ORAC) and Hydrophilicoxygen radical absorbance capacity (H-ORAC) methods, respectively, and their total is used as an indicator of the dietary antioxidant capacity of food. Antioxidants can be physically classified by their solubility into two groups: (a) lipophilic antioxidants such as vitamin $\mathrm{E}$ and carotenoids and (b) hydrophilic antioxidants such as vitamin $\mathrm{C}$ and the majority of polyphenolic compounds [39]. The ORAC values were utilized to develop individual indices for TAC in the following manner: H-ORAC, LORAC, total-oxygen radical absorbance capacity (T-ORAC) and total phenolic (TP). H-ORAC, L-ORAC, and T-ORAC are reported in $\mu \mathrm{mol}$ of Trolox equivalents per 100 grams $(\mu \mathrm{molTE} / 100 \mathrm{~g})$, while TP is reported in $\mathrm{mg}$ gallic acid equivalents per $100 \mathrm{~g}(\mathrm{mgGAE} / 100 \mathrm{~g})$ [23].

\section{The HOMA-IR calculation}

Homeostatic model assessment-insulin resistance (HOMA-IR), was calculated according to the following equation: [fasting plasma glucose $(\mathrm{mmol} / \mathrm{l}) \times$ fasting plasma insulin $(\mathrm{mIU} / \mathrm{l})] / 22.5$ [24].

\section{Definition of metabolic syndrome and its components}

Cardio-metabolic risk factors for metabolic syndrome were defined according to the diagnostic criteria proposed by Adult Treatment Panel III (ATP III) [25] and new cutoff points of WC for Iranian adults [26]; the syndrome was characterized as having at least 3 of the following metabolic abnormalities: (1) Hyperglycemia as $\mathrm{FPG} \geq 100 \mathrm{mg} / \mathrm{dl}(5.6 \mathrm{mmol} / \mathrm{l})$; (2) Hypertriglyceridemia as serum $\mathrm{TG} \geq 150 \mathrm{mg} / \mathrm{dl}(1.69 \mathrm{mmol} / \mathrm{l})$; (3) Low HDL-C serum $<40 \mathrm{mg} / \mathrm{dl}(1.04 \mathrm{mmol} / \mathrm{l})$ for men, and $<50 \mathrm{mg} / \mathrm{dl}(1.29 \mathrm{mmol} / \mathrm{l})$ for women; (4) Hypertension as $\mathrm{BP} \geq 130 / 85 \mathrm{mmHg}$; and (5) Abdominal adiposity (defined as waist circumference $88 \mathrm{~cm}$ [women] or $102 \mathrm{~cm}[\mathrm{men}])$.

\section{DNA extraction and gene sequencing}

Single nucleotide polymorphisms were selected from studies reported to be associated with CVDs or myocardial infarction (MI) [27]. All subjects from whom deoxyribonucleic acid (DNA) samples were available were expected to be genotyped for the rs 1333048. The extraction of genomic DNA from blood samples was carried out with the use of the Gene ALL DNA kit (Type G Exgene; Genall; Korea) according to the manufacturer's protocol. The concentration and purity of extracted DNA was measured using Nano Drop ND-1000 spectrophotometer. DNA was stored at $-20{ }^{\circ} \mathrm{C}$ until ready for use. 
The chromosome 9p21 rs1333048 SNP (major allele: $\mathrm{A}$; minor allele: C) was genotyped by polymerase chain reaction-restricted length polymorphism (PCR-RFLP) technique. PCR was done using the following primers: forward 5'-ACCCGAAGTAGAGCTGCAAA-3'; reverse $5^{\prime}$-CACAAGTTGGAATATGAAGCAGA- ${ }^{\prime}$. PCR reactions were performed in a final volume of $20 \mu$ contains $2 \mu \mathrm{l}$ extracted DNA, $0.5 \mu \mathrm{l}$ primers, $10 \mu \mathrm{l}$ distilled water and $7 \mu \mathrm{l} \mathrm{Taq} \mathrm{DNA} \mathrm{Polymerase} \mathrm{Master} \mathrm{Mix} \mathrm{(Ampliqon;}$ Denmark) with the following conditions in a DNA thermocycler: The DNA templates were denatured at $94^{\circ} \mathrm{C}$ for $5 \mathrm{~min}$ (min); amplification consisted of 35 cycles at $94{ }^{\circ} \mathrm{C}, 63{ }^{\circ} \mathrm{C}$ and $72{ }^{\circ} \mathrm{C}$ (each step for $30 \mathrm{~s}$ ), with a final extension at $72{ }^{\circ} \mathrm{C}$ for $7 \mathrm{~min}$. Amplified DNA $(10 \mu \mathrm{l})$ was digested with $2 \mu \mathrm{l}$ of DRI restriction enzyme (Thermo fisher scientific; United states) at $37{ }^{\circ} \mathrm{C}$ overnight. All products visualized by electrophoresis in agarose gel. Fragments containing three possible genotypes were then distinguished: uncut homozygous CC (152 bp), cut heterozygous CA (84, 68 and $152 \mathrm{bp}$ ) and cut homozygous AA ( 84 and $68 \mathrm{bp}$ ). Ten percent of the samples were directly sequenced for confirmation the PCR-RFLP results.

\section{Statistical analyses}

Normality distribution was tested by applying Kolmogorov-Smirnov's test. Data on quantitative characteristics were reported as the mean \pm SD and data on qualitative characteristics were expressed as a percentage. Qualitative variables were compared with analysis of variance (ANOVA) and independent $t$ test to compare the quantitative variables. Moreover, age, physical activity, sex, BMI and energy intake-adjusted analyses were performed in general linear models (GLM). H-ORAC, L-ORAC, T-ORAC and TP intakes were stratified into two groups: low and high intake based on the median (defined as for H-ORAC, L-ORAC, T-ORAC, TP, respectively $31894.55 \mu \mathrm{molTE} / 100 \mathrm{~g}, 38992.07 \mu \mathrm{molTE} / 100 \mathrm{~g}$, $70770.86 \mu$ molTE/100 g, 2614.81 mgGAE/100 g). Mean values for the dietary variables were adjusted for total energy intake by using the residual method [27], then the study variables were compared among two groups using an independent T-test. Genotypes of markers were recoded based on risk allele: code 0 for $\mathrm{CC}, 1$ for AC and 2 for AA genotype. In order to examine the interactions between rs1333048 genotype and TAC intakes on odds of MetS, the participants were grouped based on CDKN2B genotypes: group 1 with CC genotype $(n=76)$, group 2 with AC genotype $(n=127)$, and group 3 with AA genotype $(n=60)$. The binary logistic regression model was used to analyze potential interactions between rs1333048 genotype and TAC on odds of MetS. In this model, MetS criteria were entered as the dependent variable and rs1333048 genotypes and categorized intake of H-ORAC, L-ORAC, T-ORAC, and T based on median intakes were entered as covariates included in the crude model, and also adjusted for confunder variable also has been done at the next model. We find confounding factors with best fitted model and adjusted its effect of on exposure group, for interaction between rs 1333048 genotype and $\mathrm{H}$-ORAC intakes on odds of MetS, adjusted for sex, age, physical activity and WC and for interaction between rs1333048 genotype and L-ORAC, T-ORAC and TP intakes on odds of MetS, adjusted for sex, age, physical activity and BMI. Confounding factors were determined from a best-fit model and the change in -2 $\log$ likelihood ratio test. The level of significance was set at a probability of $<0.05$ for all tests. Statistical analysis was performed using SPSS version 22.0 (SPSS, Chicago, IL, USA).

\section{Results}

\section{Study population characteristics}

This comparative cross-sectional study was conducted on 263 participants $(52.5 \%$ female). The means $( \pm S D)$ of age, height, BMI, and weight of individuals were $35.08 \pm 8.78$ years, $168.23 \pm 9.43 \mathrm{~cm}, 25.93 \pm 4.89 \mathrm{~kg} /$ $\mathrm{m}^{2}$, and $73.51 \pm 15.66 \mathrm{~kg}$, respectively (Table 1 ). The frequencies of $A$ and $C$ alleles of rs 1333048 were $52.85 \%$ and $47.15 \%$ respectively. The overall prevalence of rs 1333048 genotypes was $22.6 \%, 47.9 \%$ and $28.7 \%$ for $\mathrm{AA}, \mathrm{AC}$ and $\mathrm{CC}$ respectively (Table 2). The distribution frequencies of mentioned SNP in this study followed Hardy-Weinberg equilibrium $(\mathrm{P}>0.05)$. It was found that $12.5 \%$ of participants had MetS, and the data demonstrated that MetS across AA, AC, CC genotypes were respectively $13.3 \%$, $11 \%$, and $13 \%(\mathrm{P}=0.86)$.

\section{Association between biochemical parameters, body composition, anthropometric measurements and rs1333048 genotypes}

A total of 263 Iranian men and women were categorized based on rs1333048 genotypes and divided into three groups: CC genotype $(n=76), A C$ genotype $(n=127)$ and AA genotype $(n=60)$ (Table 3). Means of WC, hip, $\mathrm{BMI}$, weight, FM, fat percentage and visceral fat rate (VFR) were higher in participants carrying the A allele, compared with individuals in the CC genotype, but that there was no statistically significant difference across three groups, even after adjustment for BMI, age, sex and physical activity. Also, no significant difference was observed regarding TG, T-chol, HDL-C, LDL-C, hs-CRP, systolic and diastolic blood pressure across groups, even after adjustment for confounding factors. 
Table 1 Study population characteristics

\begin{tabular}{|c|c|c|c|c|}
\hline & Min & Max & Mean & $S D^{a}$ \\
\hline \multicolumn{5}{|l|}{ Demography } \\
\hline Age (year) & 18 & 55 & 35.08 & 8.78 \\
\hline Weight (kg) & 36.50 & 142.00 & 73.51 & 15.66 \\
\hline Height (cm) & 148.00 & 193.50 & 168.23 & 9.43 \\
\hline \multicolumn{5}{|l|}{ Body composition } \\
\hline $\operatorname{BMI}\left(\mathrm{kg} / \mathrm{m}^{2}\right)$ & 18.55 & 46.22 & 25.93 & 4.89 \\
\hline Fat percentage $\%$ & 2.40 & 48.20 & 25.59 & 9.37 \\
\hline FFM (kg) & 29.93 & 104.37 & 54.28 & 9 \\
\hline Fat mass (kg) & 1.31 & 51.48 & 19.08 & 8.72 \\
\hline VFR & 1 & 17 & 5.52 & 3.40 \\
\hline BMR & 1050.00 & 2676.00 & 1603.34 & 324.27 \\
\hline Waist (cm) & 58.00 & 130.00 & 88.80 & 12.50 \\
\hline $\mathrm{Hip}(\mathrm{cm})$ & 68.00 & 144.00 & 102.62 & 9.57 \\
\hline \multicolumn{5}{|l|}{ Blood parameters } \\
\hline FBS (mmol/l) & 73.00 & 292.00 & 94.10 & 18.51 \\
\hline $\mathrm{TG}(\mathrm{mmol} / \mathrm{l})$ & 32.00 & 726.00 & 126.04 & 96.01 \\
\hline T-Chol (mmo/l) & 109.00 & 433.00 & 184.58 & 40.33 \\
\hline $\mathrm{HDL}-\mathrm{C}(\mathrm{mg} / \mathrm{dl})$ & 20.00 & 84.00 & 48.78 & 11.68 \\
\hline LDL-C (mg/dl) & 44.00 & 282.00 & 101.28 & 27.22 \\
\hline hs-CRP (mg/l) & 0.10 & 20.00 & 2.33 & 3.34 \\
\hline HOMA-IR & 0.31 & 10.54 & 2.92 & 1.56 \\
\hline \multicolumn{5}{|l|}{ Blood pressure } \\
\hline Systolic (mmHg) & 17.30 & 11.94 & 1.28 & 17.30 \\
\hline Diastolic (mmHg) & 10.90 & 7.73 & 0.91 & 10.90 \\
\hline
\end{tabular}

FBS, fast blood sugar; TG, triglyceride; T-Chol, Total cholesterol; HDL-C, High density lipoprotein cholesterol; LDL-C, low density lipoprotein cholesterol; hs-CRP, high sensitivity C-reactive protein; HOMA-IR, Homeostatic model assessment-Insulin resistance; BMI, body mass index; FFM, free fat mass;VFR, visceral fat rate; $\mathrm{BMR}$, basal metabolic rate; Hip, Hip circumference, waist, waist circumference

a Standard deviation

Table 2 rs1333048 genotypes and allelic variants of study population

\begin{tabular}{llllllll}
\hline & \multicolumn{2}{l}{$\begin{array}{l}\text { Alleles } \\
\text { frequency }\end{array}$} & & & \multicolumn{3}{l}{ Genotypes frequency } \\
\cline { 2 - 3 } \cline { 5 - 7 } \cline { 6 - 7 } & A & C & & AA & AC & CC \\
\hline rs1333048 genotypes & $47.15 \%$ & $52.85 \%$ & & $(n=60)$ & $(n=127)$ & $(n=76)$ \\
& & & & $22.6 \%$ & $47.9 \%$ & $28.7 \%$ \\
\hline
\end{tabular}

\section{Dietary intake}

After adjustment for calorie intake across rs1333048 genotypes, there were significant differences in protein $(\mathrm{P}<0.001)$, polyunsaturated fat $(\mathrm{P}=0.02)$, zinc $(\mathrm{P}=0.04)$, phosphorus $(\mathrm{P}=0.02)$, magnesium $(\mathrm{P}=0.01)$, selenium $(\mathrm{P}=0.03)$, vitamin $\mathrm{B} 3 \quad(\mathrm{P}=0.05)$, L-ORAC $\quad(\mathrm{P}=0.02)$, T-ORAC $(\mathrm{P}=0.02)$ consumption, and marginal significant differences observed in $\mathrm{H}$-ORAC $(\mathrm{P}=0.09)$. The results indicate that mean intake of H-ORAC, L-ORAC, T-ORAC and TP in the AA genotype was lower than in the CC genotype: 25,663.52, 43,613.40, 66,045.60, and 2640.56, respectively. Also, after adjustment for BMI, age, sex, and physical activity, significant differences were observed between genotypes and the intake of H-ORAC, L-ORAC, T-ORAC, protein, zinc, phosphorus, magnesium, and selenium $(\mathrm{P}<0.05)$ (Table 4$)$.

\section{Association between biochemical parameters, body composition, anthropometric measurements and TAC}

The results of the comparison indicated that means of WC, TG, and T-chol were reduced from the low intake to high intake dietary TAC, but there was no statistically significant difference, as shown in Tables 5 and 6.

\section{Genes by dietary interactions on MetS}

The binary logistic regression model analysis was used to examine the interactions between rs1333048 genotypes and H-ORAC, L-ORAC, T-ORAC and TP intake on odds of MetS.

In the crude models, there was no significant interaction between rs1333048 genotypes and TAC on the odds of MetS. After adjusting for age, sex, BMI and physical activity, a significant interaction was observed between rs1333048 genotypes and high L-ORAC intake on reduce odds of MetS $(\mathrm{OR}=0.24,95 \% \mathrm{CI}=0.06-$ 0.94, $\mathrm{P}$ for interaction $=0.04$ ). Moreover, there was no significant interaction between rs1333048 genotypes and T-ORAC and TP intake on the odds of MetS, $\mathrm{OR}=0.28,95 \% \mathrm{CI}=0.07-1.10, \mathrm{P}$ for interaction $=0.07$ and $\mathrm{OR}=0.58,95 \% \mathrm{CI}=0.16-2.07, \mathrm{P}$ for interaction $=0.40$ ) respiratory. Also, After adjusting for age, sex, WC and physical activity, a significant interaction was observed between rs1333048 genotypes and high $\mathrm{H}$-ORAC intake on reduce odds of MetS $(\mathrm{OR}=0.26$, 95\% CI $=0.06-0.99$, P for interaction $=0.04)$.

Overall, in low L-ORAC intake, percentage of MetS across AA, AC and CC genotypes were 18.9\%, 12.7\%, and $11.4 \%$, respectively. Whereas, in high L-ORAC intake, were $5 \%, 10.1 \%$, and $15.8 \%$ respectively. Also, in high $\mathrm{H}$-ORAC intake, percentage of MetS, across $\mathrm{AA}, \mathrm{AC}$ and $\mathrm{CC}$ genotypes was $12 \%, 10.9 \%$, and $17.5 \%$ respectively (Fig. 1).

In the general linear model (GLM) analysis, the associations of rs1333048 genotypes and H-ORAC, L-ORAC, T-ORAC and TP were tested on MetS components including: TG, HDL-C, LDL-C, T-chol, WC, and $\mathrm{BP}$ but there was no significant difference even after controlling for BMI, sex, age and physical activity. 
Table 3 Characteristics of study population according to rs 1333048 genotypes

\begin{tabular}{|c|c|c|c|c|c|}
\hline rs1333048 genotypes & $\begin{array}{l}C C \\
(n=76) \\
\text { Mean } \pm \text { SD }\end{array}$ & $\begin{array}{l}\text { AC } \\
(n=127) \\
\text { Mean } \pm \text { SD }\end{array}$ & $\begin{array}{l}\text { AA } \\
(n=60) \\
\text { Mean } \pm S D\end{array}$ & P value & P value* \\
\hline \multicolumn{6}{|l|}{ Demography } \\
\hline Age (years) & $34.47 \pm 8.77$ & $35.76 \pm 8.92$ & $34.35 \pm 8.66$ & 0.47 & $0.72^{* *}$ \\
\hline Height (cm) & $169.61 \pm 9.44$ & $167.75 \pm 10.05$ & $167.66 \pm 7.60$ & 0.34 & $0.42^{\mathrm{a}}$ \\
\hline Weight (kg) & $73.28 \pm 14.55$ & $72.93 \pm 15.07$ & $74.87 \pm 18.20$ & 0.73 & $0.29^{2}$ \\
\hline \multicolumn{6}{|l|}{ Body composition } \\
\hline $\mathrm{BMI}\left(\mathrm{kg} / \mathrm{m}^{2}\right)$ & $25.51 \pm 4.82$ & $25.86 \pm 4.69$ & $26.51 \pm 5.44$ & 0.50 & $0.22^{\mathrm{a}}$ \\
\hline Fat percentage $\%$ & $24.00 \pm 9.60$ & $25.97 \pm 9.74$ & $26.68 \pm 8.58$ & 0.23 & $0.81^{\mathrm{a}}$ \\
\hline Fat mass $(\mathrm{kg})$ & $18.05 \pm 8.94$ & $19.07 \pm 8.65$ & $20.34 \pm 9.01$ & 0.35 & $0.83^{\mathrm{a}}$ \\
\hline FFM (kg) & $55.71 \pm 11.63$ & $53.29 \pm 11.46$ & $54.33 \pm 13.51$ & 0.42 & $0.80^{\mathrm{a}}$ \\
\hline VFR & $5.30 \pm 3.42$ & $5.6460 \pm 3.37247$ & $5.55 \pm 3.60$ & 0.80 & $0.68^{\mathrm{a}}$ \\
\hline BMR & $1651.57 \pm 340.66$ & $1578.78 \pm 317.83$ & $1586.95 \pm 310.22$ & 0.31 & 0.33 \\
\hline Waist (cm) & $88.16 \pm 12.21$ & $88.55 \pm 12.32$ & $89.82 \pm 13.37$ & 0.74 & $0.90^{\mathrm{a}}$ \\
\hline $\mathrm{Hip}(\mathrm{cm})$ & $102.43 \pm 8.47$ & $102.50 \pm 9.70$ & $103.08 \pm 10.75$ & 0.91 & $0.06^{\mathrm{a}}$ \\
\hline \multicolumn{6}{|l|}{ Blood parameters } \\
\hline $\mathrm{FBS}(\mathrm{mmol} / \mathrm{l})$ & $94.34 \pm 17.07$ & $95.16 \pm 22.60$ & $92.03 \pm 7.57$ & 0.55 & 0.88 \\
\hline $\mathrm{TG}(\mathrm{mmol} / \mathrm{l})$ & $121.25 \pm 102.81$ & $131.28 \pm 104.70$ & $119.01 \pm 63.99$ & 0.64 & 0.96 \\
\hline T-chol (mmol/l) & $180.33 \pm 37.89$ & $189.43 \pm 43.79$ & $179.80 \pm 35.43$ & 0.17 & 0.94 \\
\hline $\mathrm{HDL}-\mathrm{C}(\mathrm{mg} / \mathrm{dl})$ & $48.26 \pm 12.51$ & $49.26 \pm 10.78$ & $48.81 \pm 12.52$ & 0.84 & 0.88 \\
\hline LDL-C (mg/dl) & $98.89 \pm 24.00$ & $104.10 \pm 30.58$ & $98.33 \pm 23.44$ & 0.27 & 0.90 \\
\hline hs-CRP (mg/l) & $2.48 \pm 3.96$ & $1.97 \pm 2.49$ & $2.87 \pm 4.01$ & 0.20 & 0.76 \\
\hline HOMA-IR & $2.79 \pm 1.41$ & $2.78 \pm 1.46$ & $3.42 \pm 1.96$ & 0.06 & 0.21 \\
\hline \multicolumn{6}{|l|}{ Blood pressure } \\
\hline Systolic (mmHg) & $11.80 \pm 1.12$ & $12.01 \pm 1.33$ & $12.00 \pm 1.37$ & 0.53 & 0.32 \\
\hline Diastolic (mmHg) & $7.67 \pm .93$ & $7.78 \pm .95$ & $7.70 \pm .80$ & 0.72 & 0.97 \\
\hline
\end{tabular}

FBS, fast blood sugar; TG, triglyceride; T-Chol, Total cholesterol; HDL-C, High density lipoprotein cholesterol; LDL, low density lipoprotein; hs-CRP, high sensitivity C-reactive protein; HOMA-IR, Homeostatic model assessment-Insulin resistance; BMI, body mass index; FFM, free fat mass;VFR, visceral fat rate; BMR, basal metabolic rate; Hip, Hip circumference, waist, waist circumference; SD, standard deviation; GLM, General Linear Model

* After adjustment for age, sex, BMl and physical activity

** Put out the collinear variable from the GLM as confounders

a BMI considered as collinear and this variable adjusted for Age, Sex and PA

\section{Discussion}

The main finding was that rs 1333048 polymorphism on chromosome 9p21 may be associated with a higher odds of MetS, and that high H-ORAC and L-ORAC intake can modify this association and reduce the odds of MetS.

Interestingly, an inverse and strong association was found between high dietary L-ORAC and H-ORAC intake and the odds of MetS across AA genotype. Generally, high dietary L-ORAC, H-ORAC and T-ORAC intake modified the association of the rs 1333048 genotypes with the odds of MetS in the AA genotype. When stratified by rs1333048 genotypes, the high dietary L-ORAC and $\mathrm{H}$-ORAC intake was only associated with a lower risk of MetS in individuals with risk alleles.

In the present study it was found that the AA genotype had mean higher fat mass and fat perecentage, although there was no statistical significance, and also that the prevalence of MetS in the AA genotype was higher than in the $\mathrm{CC}$ genotype. Teeuw et al. reported the frequency of rs1333048 genotypes was AA 35.7\%, AC 46.6\% and CC $17.9 \%$ [28]. Overall, frequency of the genotypes can vary in different populations. Several studies have shown the important role of the CDKN2A/B gene via the modulation of several pathways involved in adipocytes, pancreatic beta cells and less stable arterial plaque phenotypes [29]. Horswell et al. showed that the knockdown of CDKN2B expression in a mouse adipocyte cell line was associated with an increased level of adipogenesis [30], highlighting the importance of CDKN2B as determinant of adipogenesis.

The findings of the current study indicate that, overall, high TAC intake in the AA genotype reduces the following biochemical parameters: TG, FBS, LDL-C and hs-CRP (but without statistically significant differences). However, only high L-ORAC and T-ORAC intakes reduce $\mathrm{WC}$ in the AA genotype, in comparison with the 
Table 4 Dietary intake of study population according to rs 1333048 genotypes

\begin{tabular}{|c|c|c|c|c|c|}
\hline rs1333048 genotypes & $\begin{array}{l}C C \\
(n=76) \\
\text { Mean+SD }\end{array}$ & $\begin{array}{l}A C \\
(n=127) \\
\text { Mean+SD }\end{array}$ & $\begin{array}{l}\text { AA } \\
(n=60)\end{array}$ & $P$ value & P value* \\
\hline \multicolumn{6}{|l|}{ Macronutrient } \\
\hline Energy & $2207.08 \pm 677.06$ & $2151.12 \pm 549.72$ & $2323.82 \pm 614.59$ & 0.20 & 0.42 \\
\hline Carbohydrate & $324.64 \pm 30.20$ & $325.68 \pm 23.03$ & $319.51 \pm 24.45$ & 0.31 & 0.36 \\
\hline Protein & $79.22 \pm 12.31$ & $82.03 \pm 9.66$ & $85.52 \pm 11.90$ & $<0.001$ & $<0.001$ \\
\hline Fat & $70.41 \pm 13.37$ & $69.24 \pm 10.27$ & $71.07 \pm 10.85$ & 0.56 & 0.99 \\
\hline \multicolumn{6}{|l|}{ Carbohydrate } \\
\hline Sugar & $105.78 \pm 43.67$ & $107.81 \pm 38.03$ & $114.36 \pm 40.77$ & 0.45 & 0.38 \\
\hline Sucrose & $25.78 \pm 16.02$ & $23.95 \pm 15.12$ & $22.59 \pm 13.11$ & 0.47 & 0.30 \\
\hline Glucose & $14.15 \pm 6.56$ & $12.77 \pm 5.33$ & $13.94 \pm 5.39$ & 0.19 & 0.54 \\
\hline Fructose & $17.16 \pm 8.20$ & $15.60 \pm 6.47$ & $16.96 \pm 6.60$ & 0.24 & 0.22 \\
\hline \multicolumn{6}{|l|}{ Fatty acids } \\
\hline Saturated & $24.33 \pm 11.33$ & $22.95 \pm 9.06$ & $25.09 \pm 9.10$ & 0.34 & 0.96 \\
\hline Poly Unsaturated & $13.76 \pm 3.35$ & $12.72 \pm 3.74$ & $14.77 \pm 5.51$ & 0.02 & 0.49 \\
\hline Mono Unsaturated & $20.01 \pm 8.37$ & $19.32 \pm 6.49$ & $21.74 \pm 7.45$ & 0.11 & 0.38 \\
\hline Trans & $0.0001 \pm .00$ & $0.0001 \pm .00$ & $0.0001 \pm .00$ & 0.76 & 0.44 \\
\hline \multicolumn{6}{|l|}{ TAC } \\
\hline H-ORAC ( $\mu$ molTE/100) & $28256.75 \pm 8430.45$ & $28608.50 \pm 9150.77$ & $25663.52 \pm 7219.13$ & 0.09 & $<0.001$ \\
\hline L-ORAC ( $\mu$ molTE/100) & $49841.18 \pm 15994.96$ & $50226.96 \pm 16689.09$ & $43613.40 \pm 12833.07$ & 0.02 & 0.04 \\
\hline T-ORAC $(\mu \mathrm{molTE} / 100)$ & $74982.15 \pm 23337.82$ & $75856.27 \pm 25110.43$ & $66045.60 \pm 19363.57$ & 0.02 & 0.05 \\
\hline $\mathrm{TP}(\mathrm{mgGAE} / 100 \mathrm{~g})$ & $2820.58 \pm 657.73$ & $2855.39 \pm 663.66$ & $2640.56 \pm 520.50$ & 0.10 & 0.11 \\
\hline \multicolumn{6}{|l|}{ Mineral } \\
\hline $\mathrm{Ca}$ & $994.04 \pm 385.12$ & $1010.97 \pm 369.41$ & $1088.15 \pm 354.72$ & 0.31 & 0.07 \\
\hline Iron & $17.17 \pm 5.2$ & $17 \pm 4.5$ & $18 \pm 5.333$ & 0.10 & 0.12 \\
\hline Zinc & $11.79 \pm 3.77$ & $12.27 \pm 3.81$ & $13.45 \pm 4.09$ & 0.04 & 0.02 \\
\hline P & $1386.73 \pm 445.23$ & $1461.26 \pm 405.29$ & $1609.19 \pm 497.20$ & 0.02 & 0.02 \\
\hline $\mathrm{Mg}$ & $363.36 \pm 126.93$ & $381.63 \pm 126.44$ & $429.80 \pm 141.61$ & 0.01 & 0.01 \\
\hline Copper & $1.67 \pm 0.52$ & $1.65 \pm 0.46$ & $1.86 \pm 0.54$ & 0.20 & 0.07 \\
\hline $\mathrm{Se}$ & $122.31 \pm 41.20$ & $130.58 \pm 42.46$ & $143.27 \pm 53.70$ & 0.03 & 0.01 \\
\hline \multicolumn{6}{|l|}{ Vitamin } \\
\hline E & $9.71 \pm 4.27$ & $9.70 \pm 3.09$ & $10.71 \pm 4.17$ & 0.20 & 0.29 \\
\hline$A$ & $492.25 \pm 275.36$ & $447.43 \pm 214.48$ & $525.50 \pm 255.01$ & 0.11 & 0.77 \\
\hline C & $98.94 \pm 62.42$ & $87.20 \pm 55.52$ & $100.51 \pm 51.07$ & 0.21 & 0.74 \\
\hline D & $1.70 \pm 1.25$ & $1.69 \pm 1.19$ & $1.91 \pm 1.29$ & 0.51 & 0.48 \\
\hline B1 & $2.14 \pm 0.68$ & $2.14 \pm 5.74$ & $2.27 \pm 0.65$ & 0.41 & 0.33 \\
\hline B2 & $1.90 \pm 0.64$ & $1.92 \pm 0.61$ & $2.12 \pm 0.63$ & 0.09 & 0.13 \\
\hline B3 & $23.26 \pm 6.99$ & $22.91 \pm 6.15$ & $22.43 \pm 7.37$ & 0.05 & 0.08 \\
\hline B6 & $1.70 \pm 0.53$ & $1.71 \pm 0.52$ & $1.87 \pm 0.54$ & 0.12 & 0.14 \\
\hline $\mathrm{B} 12$ & $3.83 \pm 1.67$ & $3.98 \pm 1.68$ & $4.1 \pm 1.31$ & 0.46 & 0.26 \\
\hline
\end{tabular}

Italic values indicate significance of $p$ value $(p<0.05)$

TAC, total antioxidant capacity; H-ORAC, hydrophilic oxygen radical absorbance capacity; L-ORAC, lyophilic oxygen radical absorbance capacity; T-ORAC, total -oxygen radical absorbance capacity; TP, total phenolic; $\mu$ molTE, $\mu$ mol of Trolox equivalents; $m g G A E$, mg gallic acid equivalents

* After adjustment for calories intake

$\mathrm{CC}$ and $\mathrm{AC}$ genotypes, with a statistically significant difference. In fact, an increased consumption of antioxidant-rich foods, such as fruits, vegetables, olive oil, nuts, and seafood resulted in an improvement in lipid profiles, with increased HDL-C and decreased LDL-C, in some intervention trial studies [31]. Some studies have shown the importance of oxidative stress in the physiopathology of obesity, and MetS has demonstrated that oxidative 
Table 5 Characteristics of study population based on median intake H-ORAC and L-ORAC

\begin{tabular}{|c|c|c|c|c|c|c|c|c|}
\hline \multirow[t]{2}{*}{ Intake } & \multicolumn{4}{|l|}{ H-ORAC } & \multicolumn{4}{|l|}{ L-ORAC } \\
\hline & $\begin{array}{l}\text { Low } \\
\text { Mean } \pm \text { SD }\end{array}$ & $\begin{array}{l}\text { High } \\
\text { Mean } \pm \text { SD }\end{array}$ & P value & P value* & $\begin{array}{l}\text { Low } \\
\text { Mean } \pm S D\end{array}$ & $\begin{array}{l}\text { High } \\
\text { Mean } \pm \text { SD }\end{array}$ & P value & P value* \\
\hline \multicolumn{9}{|l|}{ Demography } \\
\hline Age (years) & $34.46 \pm 8.55$ & $35.40 \pm 9.00$ & 0.40 & 0.29 & $35.38 \pm 8.76$ & $34.48 \pm 8.90$ & 0.41 & 0.83 \\
\hline Height (cm) & $168.31 \pm 9.2$ & $168.37 \pm 9.75$ & 0.96 & 0.82 & $168.83 \pm 9.58$ & $167.84 \pm 9.43$ & 0.40 & 0.10 \\
\hline Weight (kg) & $73.03 \pm 15.9$ & $73.78 \pm 15.67$ & 0.70 & 0.79 & $73.50 \pm 16.14$ & $73.31 \pm 15.43$ & 0.92 & 0.63 \\
\hline \multicolumn{9}{|l|}{ Body composition } \\
\hline $\mathrm{BMI}\left(\mathrm{kg} / \mathrm{m}^{2}\right)$ & $25.74 \pm 5.03$ & $25.96 \pm 4.69$ & 0.72 & 0.86 & $25.73 \pm 5.01$ & $25.97 \pm 4.71$ & 0.70 & 0.96 \\
\hline Fat percentage $\%$ & $25.04 \pm 9.61$ & $25.89 \pm 9.00$ & 0.47 & 0.25 & $25.38 \pm 8.99$ & $25.56 \pm 8.99$ & 0.87 & 0.50 \\
\hline Fat mass & $18.28 \pm 8.4$ & $20.01 \pm 9.07$ & 0.13 & 0.14 & $16.57 \pm 8.24$ & $21.74 \pm 8.59$ & $<0.001$ & $<0.001$ \\
\hline FFM & $60.11 \pm 11.76$ & $47.48 \pm 8.2$ & $<0.001$ & $<0.001$ & $62.83 \pm 9.80$ & $44.74 \pm 5.03$ & $<0.001$ & $<0.001$ \\
\hline VFR & $5.31 \pm 3.53$ & $5.59 \pm 3.20$ & 0.51 & 0.77 & $5.39 \pm 3.53$ & $5.52 \pm 3.20$ & 0.77 & 0.68 \\
\hline BMR & $1602.46 \pm 320.63$ & $1603.89 \pm 333.41$ & 0.97 & 0.66 & $1605.92 \pm 334.46$ & $1600 \pm 319.61$ & 0.89 & 0.07 \\
\hline Waist (cm) & $88.55 \pm 13.07$ & $88.53 \pm 11.95$ & 0.98 & 0.29 & $89.02 \pm 13.11$ & $88.06 \pm 11.84$ & 0.55 & 0.03 \\
\hline Hip (cm) & $102.15 \pm 9.77$ & $102.70 \pm 9.26$ & 0.65 & 0.90 & $102.80 \pm 9.74333$ & $102.05 \pm 9.27$ & 0.53 & 0.10 \\
\hline \multicolumn{9}{|l|}{ Blood parameters } \\
\hline FBS (mmol/L) & $93.29 \pm 20.6$ & $94.75 \pm 16.72$ & 0.53 & 0.57 & $93.43 \pm 20.61$ & $94.62 \pm 16.75$ & 0.61 & 0.49 \\
\hline $\mathrm{TG}(\mathrm{mmol} / \mathrm{L})$ & $130.8 \pm 108$ & $119.3 \pm 9.92$ & 0.31 & 0.27 & $131.13 \pm 108.82$ & $118.94 \pm 69.19$ & 0.28 & 0.24 \\
\hline T-chol (mmol/L) & $184.1 \pm 40.5$ & $183.89 \pm 37.6$ & 0.95 & 0.59 & $186.13 \pm 41.34$ & $181.92 \pm 36.57$ & 0.39 & 0.33 \\
\hline $\mathrm{HDL}-\mathrm{C}(\mathrm{mg} / \mathrm{dl})$ & $48.3 \pm 11.89$ & $49.05 \pm 11.53$ & 0.62 & 0.45 & $48.62 \pm 12.18$ & $48.77 \pm 11.22$ & 0.92 & 0.78 \\
\hline LDL-C (mg/dl) & $100.3 \pm 26.7$ & $101.51 \pm 26.2$ & 0.71 & 0.88 & $101.81 \pm 27.64$ & $100.01 \pm 25.30$ & 0.58 & 0.47 \\
\hline hs-CRP (mg/l) & $2.22 \pm 3.33$ & $2.38 \pm 3.36$ & 0.69 & 0.41 & $2.35 \pm 3.39$ & $2.25 \pm 3.30$ & 0.80 & 0.95 \\
\hline HOMA-IR & $2.94 \pm 1.67$ & $2.90 \pm 1.50$ & 0.87 & 0.84 & $2.82 \pm 1.53$ & $3.01 \pm 1.63$ & 0.44 & 0.40 \\
\hline \multicolumn{9}{|l|}{ Blood pressure } \\
\hline Systolic (mmHg) & $11.82 \pm 1.33$ & $12.0 \pm 1.25$ & 0.19 & 0.11 & $11.88 \pm 1.32$ & $11.99 \pm 1.27$ & 0.52 & 0.33 \\
\hline Diastolic $(\mathrm{mmHg})$ & $7.70 \pm .98$ & $7.75 \pm .84$ & 0.68 & 0.67 & $7.731 \pm .93$ & $7.72 \pm 0.90$ & 0.96 & 0.93 \\
\hline
\end{tabular}

FBS, fast blood sugar; TG, triglyceride; T-Chol, Total cholesterol; HDL-C, High density lipoprotein cholesterol; LDL-C, low density lipoprotein cholesterol; hs-CRP, high sensitivity C-reactive protein; HOMA-IR, Homeostatic model assessment-Insulin resistance; BMI, body mass index; FFM, free fat mass ;VFR, visceral fat rate; BMR, basal metabolic rate; Hip, Hip circumference, waist, waist circumference; *standard deviation; TAC, total antioxidant capacity; $\mathrm{H}-\mathrm{ORAC}$, hydrophilic oxygen radical absorbance capacity; L-ORAC, lyophilic oxygen radical absorbance capacity; Total-ORAC, total -oxygen radical absorbance capacity; TP, total phenolic, GLM, general linear models

* After adjustment for calories intake. H-ORAC, L-ORAC, were stratified into two groups low and high intake based on median (defined as or cut point for H-ORAC, L-ORAC, respectively $31894.55 \mu \mathrm{molTE} / 100 \mathrm{~g}, 38992.07 \mu \mathrm{molTE} / 100 \mathrm{~g}$ )

stress values increase with the number of components of MetS, and also that fat accumulation is closely correlated with markers of systemic oxidative stress [32, 33]. In fact, increased oxidative stress in accumulated fat leads to dysregulated adipocytokines production [34].

To the best of this team's knowledge, this is the first study evaluating the interactions between genetic variants of the 9p21 locus with H-ORAC, L-ORAC, T-ORAC and TP. The current study indicates that the intakes of L-ORAC and T-ORAC in individuals with an AA genotype was lower in comparison with $\mathrm{CC}$ and $\mathrm{AC}$ genotypes, and there was a statistically significant difference. The results illustrated an interaction between rs 1333048 A allele and high L-ORAC intake with a reduced odds of MetS. In fact, low L-ORAC intakes in subjects with A alleles increases the odds of MetS, but when L-ORAC and $\mathrm{H}$-ORAC intake increases, it leads to a reduced odds of MetS in the AA genotypes, not seen in other genotypes. Also, T-ORAC intakes in the AA genotype reduces the odss of MetS, but with only marginal significant differences, while TP intake has no effect on the odds of MetS across all genotypes. The transcription factors in lipophilic binding in the CDKN2B gene promoters are PKNOX1, SOX5, ZSCAN4, and HDGF, which regulate cell cycles and coding proteins [35]. Thus, it was hypothesized that the mechanism of this interaction between the AA genotype and high L-ORAC intake with a reduced risk of MetS might be via transcription factor lipophilic, which can bind lipophilic antioxidants, including vitamin $\mathrm{E}$ and carotenoids. One regulatory mechanism of CDKN2A/B expression is through epigenetic mechanisms directed by ANRIL [36]. If epigenetic mechanisms contribute to the association between $9 \mathrm{p} 21$ and CVD, the current results suggest that they could 
Table 6 Characteristics of study population based on median intake T-ORAC and TP

\begin{tabular}{|c|c|c|c|c|c|c|c|c|}
\hline \multirow[t]{2}{*}{ Intake } & \multicolumn{4}{|l|}{ T-ORAC } & \multicolumn{4}{|l|}{ TP } \\
\hline & $\begin{array}{l}\text { Low } \\
\text { Mean } \pm \text { SD }\end{array}$ & $\begin{array}{l}\text { High } \\
\text { Mean } \pm \text { SD }\end{array}$ & $P$ value & P value* & $\begin{array}{l}\text { Low } \\
\text { Mean } \pm S D\end{array}$ & $\begin{array}{l}\text { High } \\
\text { Mean } \pm S D\end{array}$ & $P$ value & Pvalue* $^{*}$ \\
\hline \multicolumn{9}{|l|}{ Demography } \\
\hline Age (years) & $35.22 \pm 8.774$ & $34.65 \pm 8.909$ & 0.60 & 0.90 & $34.90 \pm 8.55$ & $34.97 \pm 9.13$ & 0.94 & 0.94 \\
\hline Height (cm) & $169.14 \pm 9.347$ & $167.53 \pm 9.6$ & 0.17 & 0.14 & $168.95 \pm 9.64$ & $167.72 \pm 9.35$ & 0.30 & 0.30 \\
\hline Weight (kg) & $73.82 \pm 16.15$ & $72.99 \pm 15.41$ & 0.67 & 0.63 & $74.05 \pm 15.67$ & $72.76 \pm 15.92$ & 0.51 & 0.51 \\
\hline \multicolumn{9}{|l|}{ Body composition } \\
\hline $\mathrm{BMI}\left(\mathrm{kg} / \mathrm{m}^{2}\right)$ & $25.76 \pm 5.04$ & $25.95 \pm 4.67$ & 0.75 & 0.99 & $25.90 \pm 4.85$ & $25.79 \pm 4.88$ & 0.86 & 0.86 \\
\hline Fat percentage \% & $25.10 \pm 9.76$ & $25.84 \pm 8.84$ & 0.53 & 0.61 & $24.66 \pm 9.50$ & $26.28 \pm 9.06$ & 0.17 & 0.30 \\
\hline Fat mass & $16.92 \pm 8.27$ & $21.38 \pm 8.76$ & $<0.001$ & $<0.001$ & $18.40 \pm 8.34$ & $19.92 \pm 9.21$ & 0.18 & 0.17 \\
\hline FFM & $62.11 \pm 10.45$ & $45.47 \pm 6.13$ & $<0.001$ & $<0.001$ & $59.46 \pm 12.34$ & $47.93 \pm 8.09$ & $<0.001$ & $<0.001$ \\
\hline VFR & $5.47 \pm 3.59$ & $5.43 \pm 3.14$ & 0.92 & 0.82 & $5.54 \pm 3.51$ & $5.37 \pm 3.23$ & 0.69 & 0.95 \\
\hline BMR & $1617.07 \pm 328.94$ & $1589.30 \pm 324.72$ & 0.50 & 0.12 & $1628.19 \pm 323.57$ & $1578.18 \pm 328.75$ & 0.23 & 0.71 \\
\hline Waist (cm) & $89.06 \pm 13.20$ & $88.02 \pm 11.76$ & 0.51 & 0.05 & $89.12 \pm 12.60$ & $87.97 \pm 12.39$ & 0.47 & 0.47 \\
\hline $\mathrm{Hip}(\mathrm{cm})$ & $102.73 \pm 9.74$ & $102.13 \pm 9.28$ & 0.62 & 0.15 & $102.34 \pm 9.39$ & $102.52 \pm 9.64$ & 0.87 & 0.87 \\
\hline \multicolumn{9}{|l|}{ Blood parameters } \\
\hline FBS (mmol/L) & $93.40 \pm 20.58$ & $94.66 \pm 16.79$ & 0.59 & 0.41 & $93.44 \pm 20.51$ & $94.61 \pm 16.92$ & 0.61 & 0.61 \\
\hline TG (mmol/L) & $132.25 \pm 108.91$ & $117.81 \pm 68.83$ & 0.20 & 0.26 & $135.23 \pm 110.41$ & $114.96 \pm 66.07$ & 0.07 & 0.07 \\
\hline T-chol (mmol/L) & $185.71 \pm 41.15$ & $182.34 \pm 36.83$ & 0.49 & 0.43 & $185.97 \pm 39.59$ & $182.11 \pm 38.50$ & 0.43 & 0.43 \\
\hline $\mathrm{HDL}-\mathrm{C}(\mathrm{mg} / \mathrm{dl})$ & $48.47 \pm 12.34$ & $48.92 \pm 11.04$ & 0.76 & 0.89 & $48.40 \pm 11.77$ & $48.99 \pm 11.65$ & 0.68 & 0.68 \\
\hline LDL-C (mg/dl) & $101.48 \pm 27.44$ & $100.34 \pm 25.53$ & 0.73 & 0.64 & $101.48 \pm 26.59$ & $100.35 \pm 26.42$ & 0.73 & 0.73 \\
\hline hs-CRP (mg/l) & $2.36 \pm 3.39$ & $2.24 \pm 3.30$ & 0.76 & 0.98 & $2.20 \pm 3.18$ & $2.40 \pm 3.5$ & 0.62 & 0.62 \\
\hline HOMA-IR & $2.98 \pm 1.65$ & $2.85 \pm 1.51$ & 0.62 & 0.63 & $2.83 \pm 1.44$ & $3.00 \pm 1.70$ & 0.49 & 0.41 \\
\hline \multicolumn{9}{|l|}{ Blood pressure } \\
\hline Systolic (mmHg) & $11.86 \pm 1.32$ & $12.00 \pm 1.27$ & 0.41 & 0.16 & $11.86 \pm 1.34$ & $12.00 \pm 1.24$ & 0.40 & 0.08 \\
\hline Diastolic (mmHg) & $7.71 \pm .94$ & $7.73 \pm .88$ & 0.85 & 0.67 & $7.71 \pm .94$ & $7.73 \pm 0.88$ & 0.86 & 0.57 \\
\hline
\end{tabular}

FBS, fast blood sugar; TG, triglyceride; T-Chol, Total cholesterol; HDL-C, High density lipoprotein cholesterol; LDL-C, low density lipoprotein cholesterol; hs-CRP, high sensitivity C-reactive protein; HOMA-IR, Homeostatic model assessment-Insulin resistance; BMI, body mass index; FFM, free fat mass ;VFR, visceral fat rate; BMR, basal metabolic rate; Hip, Hip circumference, waist, waist circumference; * ${ }^{*}$ tandard deviation; TAC, total antioxidant capacity; T-ORAC, total-oxygen radical absorbance capacity; TP, total phenolic, GLM, general linear models

* After adjustment for calories intake. T-ORAC and TP intake were stratified into two groups low and high intake based on median (defined as or cut point for TotalORAC, TP, respectively; $70770.86 \mu \mathrm{molTE} / 100 \mathrm{~g}, 2614.81 \mathrm{mgGAE} / 100 \mathrm{~g}$ )

potentially be influenced by nutritional or environmental factors and through gene-environment interactions. Milagro et al. reported possible associations between genetic variations at this locus with obesity as important risk factors for CVDs, as well as its association with environmental factors such as dietary intake [35]. Similarly, Qi et al. studied the interactions between genetic backgrounds and dietary patterns in diabetes subjects. They found that a western dietary pattern might elevate diabetes risk, particularly among subjects with mutations in this locus [36].

The favorable effects of these antioxidant-rich foods on the improvement of lipid profiles, glucose homeostasis, insulin resistance, adiposity and obesity have been investigated in pre-clinical and some clinical studies [37]. In addition, dietary antioxidants also affect other aspects of obesity-related metabolic pathways, including the inhibition of intestinal fat abortion, the promotion of catabolism in adipose tissue, the inhibition of proliferation, differentiation, and angiogenesis in pre-adipocytes, and the induction of apoptosis in mature adipocytes [38]. Some other dietary antioxidants could prevent adiposity by regulating brown adipose tissue metabolism and increasing thermogenesis, decreasing adiponectin and leptin gene expression in adipocytes [39].

Strength of this study is that it is the first study to evaluate the interaction between rs1333048 genotypes and TAC on the odds of MetS in subjects, and that it was a community-based study. The main limitation of the present study was the relatively small number of subjects and the low prevalence of MetS. Also, the cross-sectional design of the study, in which it was not possible to determine the mechanism of the 


\section{a H-ORAC}

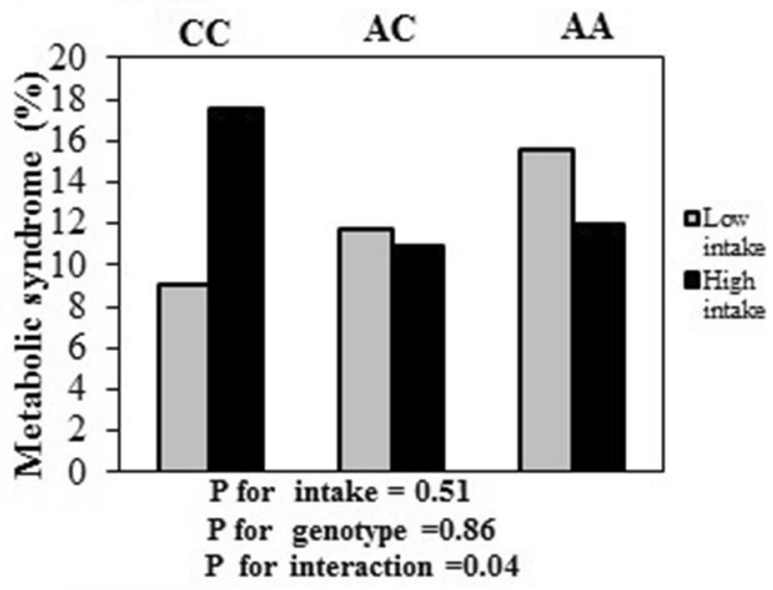

C T-ORAC

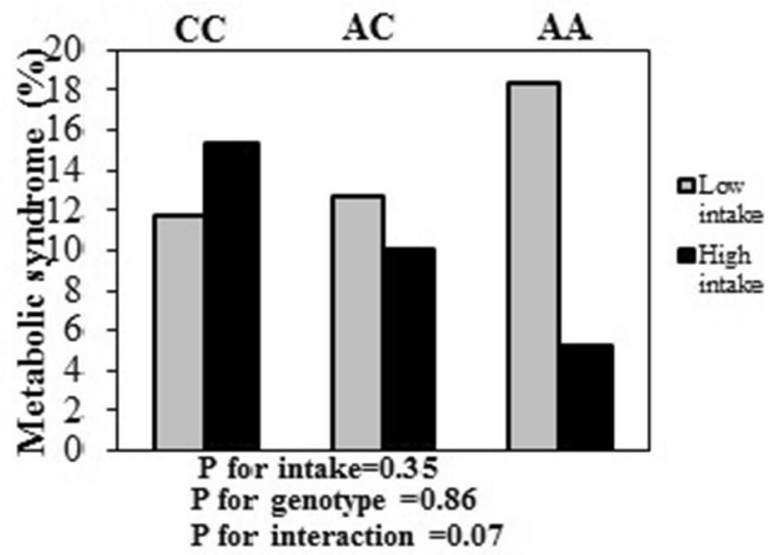

b L-ORAC
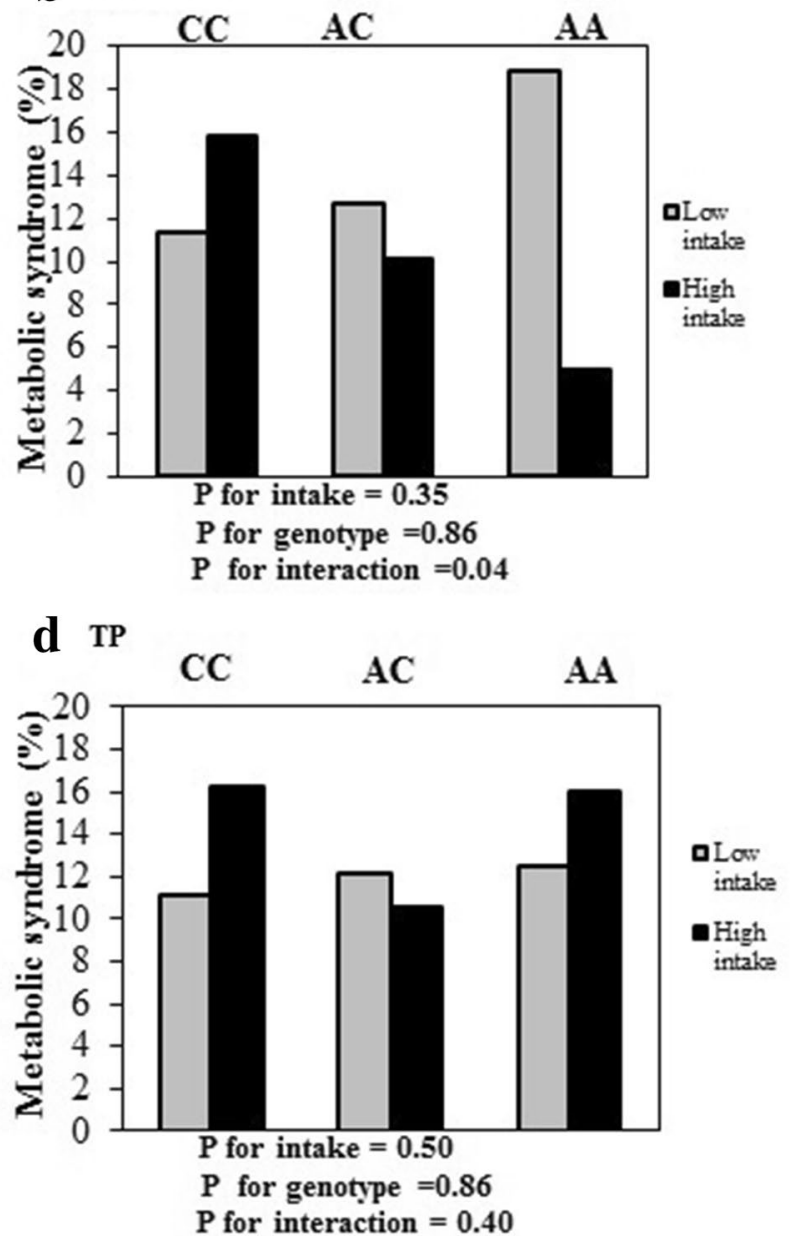

Fig. 1 Percentage of MetS across rs1333048 genotypes base on low and high dietary TAC. Percentage of MetS across AA, AC and CC genotypes base on low and high dietary TAC. a Percentage of MetS across AA, AC and CC genotypes base on low and high H-ORAC intake. Percentage of MetS in low intake across AA, AC and CC genotypes were respiratory 15.6\%, 11.7\% and 9.1\%. Percentage of MetS in high intake across AA, AC and CC genotypes were respiratory $12.0 \%, 10.9 \%$ and $17.5 \%$. b Percentage of MetS across AA, AC and CC genotypes base on low and high L-ORAC intake. Percentage of MetS in low intake across AA, AC and CC genotypes were respiratory 18.9\%, 12.7\% and 11.4\%. Percentage of MetS in high intake across AA, AC and CC genotypes were respiratory 5\%, 10.1\% and 15.8\%. c Percentage of MetS across AA, AC and CC genotypes base on low and high T-ORAC intake. Percentage of MetS in low intake across AA, AC and CC genotypes were respiratory $18.4 \%, 12.7 \%$ and $11.8 \%$. Percentage of MetS in high intake across AA, AC and CC genotype were respiratory 5.3\%, 10.1\% and 15.4\%. d Percentage of MetS across AA, AC and CC genotypes base on low and high TP intake. Percentage of MetS in low intake across AA, AC and CC genotypes were respiratory $12.5 \%, 12.1 \% 11.1 \%$. Percentage of MetS in high intake across AA, AC and CC genotypes were respiratory $16.0 \%, 10.6 \%$ and $16.2 \%$

relationship between L-ORAC/H-LORAC and the rs1333048 genotype could be considered as a limitation.

\section{Conclusion}

The findings of this study suggest that high L-ORAC and $\mathrm{H}$-LORAC intake can reduce the odds of MetS in the AA genotype. The present evidence indicates that this could be a novel link between TAC and rs1333048 genotypes. However, the mechanism of interaction between L-ORAC/H-ORAC and AA genotypes is not clearly understood. This study provides further evidence to recommend antioxidant-rich foods as a useful tool in health promotion and disease prevention.

\section{Abbreviations}

ANOVA: analysis of variance; ATPIII: Adult Treatment Panel III; BIA: Bioelectrical Impedance Analyzer; BMI: body mass index; CHDs: chronic heart diseases; CVDs: cardiovascular diseases; CDKN2B: cyclin-dependent kinase inhibitor 2 B; DNA: deoxyribonucleic acid; DXA: dual energy X-ray absorptiometry; FFQ: food frequency questionnaire; FCT: food composition table; GLM: general linear model; GOD/PAP: glucose oxidase phenol 4-aminoantipyrine peroxidase; GPOPAP: glycerol-3-phosphate oxidase phenol 4-aminoantipyrine peroxidase; 
GWAS: genome-wide association studies; H-ORAC: hydrophilic oxygen radical absorbance capacity; HDL: high-density lipoprotein Cholesterol; hs-CRP: hypersensitive C-reactive protein; FPG: fasting plasma Glucose; LDL: low-density lipoprotein; L-ORAC: Iyophilic oxygen radical absorbance capacity; MetS: metabolic syndrome; MI: myocardial infarction; ORAC: oxygen radical absorbance capacity; PCR-RFLP: polymerase chain reactions-restriction fragment length polymorphism; ROS: reactive oxygen species; SNPs: single-nucleotide polymorphisms; TAC: total antioxidant capacity; T-ORAC: total oxygen radical absorbance capacity; TP: total phenolic; T2D: type 2 diabetes; TG: triglycerides; T-chol: total cholesterol; VFR: visceral fat rate; WC: waist circumference.

\section{Authors' contributions}

The project was designed and implemented by AM and KhM. Data were analyzed and interpreted AM and MY, AM, MM, MR, RS and ZhM prepared the manuscript. KhM, supervised overall project. All authors read and approved the final manuscript.

\section{Author details}

${ }^{1}$ Department of Community Nutrition, School of Nutritional Sciences and Dietetics, Tehran University of Medical Sciences (TUMS), P.O. Box: 14155-6117, Tehran, Iran. ${ }^{2}$ Department of Epidemiology and Biostatistics, School of Public Health, Tehran University of Medical Sciences (TUMS), Tehran, Iran. ${ }^{3}$ Endocrinology and Metabolism Clinical Sciences Institute, Tehran University of Medical Sciences (TUMS), Tehran, Iran.

\section{Acknowledgements}

The authors thank the study participants for their cooperation and assistance in physical examinations. They also thank those involved in nutritional evaluation and database management, as well as the Osteoporosis Research Center, Endocrine Diseases and Metabolism Research Institute, Tehran University of Medical Sciences.

\section{Competing interests}

The authors declare that they have no competing interests.

\section{Availability of data and materials}

The data that support the findings of this study are available from Khadijeh Mirzaei but restrictions apply to the availability of these data, which were used under license for the current study, and so are not publicly available. Data are however available from the authors upon reasonable request and with permission of Khadijeh Mirzaei.

\section{Consent for publication}

Each participant was completely informed about the study protocol and provided a written and informed consent form before taking part in the study.

\section{Ethics approval and consent to participate}

The study protocol has approved by the ethics committee of Endocrinology and Metabolism Research Center of Tehran University of Medical Sciences (TUMS) with the following identification: 93-04-161-27-722-1495-80.

\section{Funding}

This study was supported by the Osteoporosis Research Center, Endocrine Diseases and Metabolism Research Institute, Tehran University of Medical Sciences, and by Grants from Tehran University of Medical Sciences (Grants ID: 93-04-161-27-722 and 93-04-159-280-31).

\section{Publisher's Note}

Springer Nature remains neutral with regard to jurisdictional claims in published maps and institutional affiliations.

Received: 29 May 2018 Accepted: 14 September 2018 Published online: 18 October 2018

\section{References}

1. Alberti KG, Eckel RH, Grundy SM, Zimmet PZ, Cleeman Jl, Donato KA, et al. Harmonizing the metabolic syndrome: a joint interim statement of the International Diabetes Federation Task Force on Epidemiology and
Prevention; National Heart, Lung, and Blood Institute; American Heart Association; World Heart Federation; International Atherosclerosis Society; and International Association for the Study of Obesity. Circulation. 2009;120(16):1640-5.

2. Ando K, Fujita T. Metabolic syndrome and oxidative stress. Free Rad Biol Med. 2009;47(3):213-8.

3. Valko M, Leibfritz D, Moncol J, Cronin MT, Mazur M, Telser J. Free radicals and antioxidants in normal physiological functions and human disease. Int J Biochem Cell Biol. 2007;39(1):44-84.

4. Nakazono K, Watanabe N, Matsuno K, Sasaki J, Sato T, Inoue M. Does superoxide underlie the pathogenesis of hypertension? Proc Natl Acad Sci USA. 1991;88(22):10045-8.

5. Kajimoto $Y$, Kaneto $H$. Role of oxidative stress in pancreatic $\beta$-cell dysfunction. Ann NY Acad Sci. 2004;1011(1):168-76.

6. Ohara Y, Peterson TE, Harrison DG. Hypercholesterolemia increases endothelial superoxide anion production. J Clin Investig. 1993;91(6):2546-51.

7. Frei B. Efficacy of dietary antioxidants to prevent oxidative damage and inhibit chronic disease. J Nutr. 2004;134(11):3196S-8S.

8. Agudo A, Cabrera L, Amiano P, Ardanaz E, Barricarte A, Berenguer T, et al. Fruit and vegetable intakes, dietary antioxidant nutrients, and total mortality in Spanish adults: findings from the Spanish cohort of the European Prospective Investigation into Cancer and Nutrition (EPIC-Spain). Am J Clin Nutr. 2007:85(6):1634-42.

9. Wu X, Gu L, Holden J, Haytowitz DB, Gebhardt SE, Beecher G, et al. Development of a database for total antioxidant capacity in foods: a preliminary study. J Food Compos Anal. 2004;17(3):407-22.

10. Puchau B, Zulet MÁ, de Echávarri AG, Hermsdorff HHM, Martínez JA. Dietary total antioxidant capacity: a novel indicator of diet quality in healthy young adults. J Am Coll Nutr. 2009;28(6):648-56.

11. Pellegrini N, Serafini M, Salvatore S, Del Rio D, Bianchi M, Brighenti F. Total antioxidant capacity of spices, dried fruits, nuts, pulses, cereals and sweets consumed in Italy assessed by three different in vitro assays. Mol Nutr Food Res. 2006;50(11):1030-8.

12. Hermsdorff HHM, Puchau B, Volp ACP, Barbosa KB, Bressan J, Zulet MÁ, et al. Dietary total antioxidant capacity is inversely related to central adiposity as well as to metabolic and oxidative stress markers in healthy young adults. Nutr Metab. 2011;8(1):59.

13. Brighenti F, Valtuena S, Pellegrini N, Ardigo D, Del Rio D, Salvatore S, et al. Total antioxidant capacity of the diet is inversely and independently related to plasma concentration of high-sensitivity C-reactive protein in adult Italian subjects. Br J Nutr. 2005;93(5):619-25.

14. Zeller T, Blankenberg S, Diemert P. Genomewide association studies in cardiovascular disease —an update 2011. Clin Chem. 2012;58(1):92-103.

15. Paynter NP, Chasman DI, Buring JE, Shiffman D, Cook NR, Ridker PM. Cardiovascular disease risk prediction with and without knowledge of genetic variation at chromosome 9p21. 3. Ann Intern Med. 2009;150(2):65-72.

16. Wahlstrand B, Orho-Melander M, Delling L, Kjeldsen S, Narkiewicz K, Almgren $\mathrm{P}$, et al. The myocardial infarction associated CDKN2A/CDKN2B locus on chromosome 9 p21 is associated with stroke independently of coronary events in patients with hypertension. J Hypertens. 2009;27(4):769-73.

17. Ordovas JM, Tai ES. Why study gene-environment interactions? Curr Opin Lipidol. 2008;19(2):158-67.

18. Mente A, de Koning L, Shannon HS, Anand SS. A systematic review of the evidence supporting a causal link between dietary factors and coronary heart disease. Arch Intern Med. 2009;169(7):659-69.

19. Ornish D, Scherwitz LW, Billings JH, Gould KL, Merritt TA, Sparler S, et al. Intensive lifestyle changes for reversal of coronary heart disease. JAMA. 1998;280(23):2001-7.

20. Hosseini-Esfahani F, Jessri M, Mirmiran P, Bastan S, Azizi F. Adherence to dietary recommendations and risk of metabolic syndrome: tehran Lipid and Glucose Study. Metabolism. 2010;59(12):1833-42.

21. Valtuena S, Pellegrini N, Franzini L, Bianchi MA, Ardigo D, Del Rio D, et al. Food selection based on total antioxidant capacity can modify antioxidant intake, systemic inflammation, and liver function without altering markers of oxidative stress. Am J Clin Nutr. 2008;87(5):1290-7.

22. Limberaki E, Eleftheriou P, Vagdatli E, Kostoglou V, Petrou C. Serum antioxidant status among young, middle-aged and elderly people before and after antioxidant rich diet. Hippokratia. 2012;16(2):118. 
23. Speisky H, López-Alarcón C, Gómez M, Fuentes J, Sandoval-Acuña C. First web-based database on total phenolics and oxygen radical absorbance capacity (ORAC) of fruits produced and consumed within the south Andes region of South America. J Agric Food Chem. 2012;60(36):8851-9.

24. Mirzaei K, Hossein-Nezhad A, Keshavarz S, Eshaghi S, Koohdani F, SaboorYaraghi A, et al. Insulin resistance via modification of PGC1 a function identifying a possible preventive role of vitamin $D$ analogues in chronic inflammatory state of obesity. A double blind clinical trial study. Minerva Med. 2014;105(1):63-78.

25. Grundy SM, Cleeman JI, Daniels SR, Donato KA, Eckel RH, Franklin BA, et al. Diagnosis and management of the metabolic syndrome: an American Heart Association/National Heart, Lung, and Blood Institute Scientific Statement. Circulation. 2005;112(17):2735-52.

26. Azizi F, Hadaegh F, Khalili D, Esteghamati A, Hosseinpanah F, Delavari A, et al. Appropriate definition of metabolic syndrome among Iranian adults: report of the Iranian National Committee of Obesity. Arch Iran Med. 2010;13(5):426-8.

27. Willett W. Issues in analysis and presentation of dietary data. In: Willett WC, editor. Nutritional epidemiology. 2nd ed. New York: Oxford University Press; 1998. p. 321-46.

28. Teeuw WJ, Laine ML, Bizzarro S, Loos BG. A Lead ANRIL Polymorphism Is Associated with Elevated CRP Levels in Periodontitis: A Pilot Case-Control Study. PloS one. 2015;10(9):e0137335. PubMed PMID: 26348353. Pubmed Central PMCID: PMC4562619. Epub 2015/09/09. eng.

29. Spalding KL, Arner E, Westermark PO, Bernard S, Buchholz BA, Bergmann $O$, et al. Dynamics of fat cell turnover in humans. Nature. 2008;453(7196):783-7.

30. Horswell SD, Fryer LG, Hutchison CE, Zindrou D, Speedy HE, Town MM, et al. CDKN2B expression in adipose tissue of familial combined hyperlipidaemia patients. J Lipid Res. 2013;54(12):3491-505.
31. Hermsdorff HHM, Zulet MÁ, Abete I, Martínez JA. A legume-based hypocaloric diet reduces proinflammatory status and improves metabolic features in overweight/obese subjects. Eur J Nutr. 2011;50(1):61-9.

32. Keaney JF, Larson MG, Vasan RS, Wilson PW, Lipinska I, Corey D, et al. Obesity and systemic oxidative stress. Arterioscler Thromb Vasc Biol. 2003;23(3):434-9.

33. Fujita K, Nishizawa H, Funahashi T, Shimomura I, Shimabukuro M. Systemic oxidative stress is associated with visceral fat accumulation and the metabolic syndrome. Circ J. 2006;70(11):1437-42.

34. Furukawa S, Fujita T, Shimabukuro M, Iwaki M, Yamada Y, Nakajima Y, et al. Increased oxidative stress in obesity and its impact on metabolic syndrome. J Clin Investig. 2017;114(12):1752-61.

35. http://www.genecards.org. Accessed 13 Sept 2017.

36. Cunnington MS, et al. Chromosome 9p21 SNPs associated with multiple disease phenotypes correlate with ANRIL expression. PLoS Genet. 2010;6(4):e1000899.

37. Meydani M, Hasan ST. Dietary polyphenols and obesity. Nutrients. 2010;2(7):737-51

38. Lee M-S, Kim C-T, Kim Y. Green tea (-)-epigallocatechin-3-gallate reduces body weight with regulation of multiple genes expression in adipose tissue of diet-induced obese mice. Ann Nutr Metab. 2009;54(2):151-7.

39. Detopoulou P, Panagiotakos D, Chrysohoou C, Fragopoulou E, Nomikos T, Antonopoulou S, et al. Dietary antioxidant capacity and concentration of adiponectin in apparently healthy adults: the ATTICA study. Eur J Clin Nutr. 2010;64(2):161.
Ready to submit your research? Choose BMC and benefit from:

- fast, convenient online submission

- thorough peer review by experienced researchers in your field

- rapid publication on acceptance

- support for research data, including large and complex data types

- gold Open Access which fosters wider collaboration and increased citations

- maximum visibility for your research: over 100M website views per year

At BMC, research is always in progress.

Learn more biomedcentral.com/submissions 